\title{
Occurrence of strong and very strong heat stress in Poland and its circulation conditions
}

\author{
Arkadiusz M. Tomczyk ${ }^{1}$ (D) Małgorzata Owczarek ${ }^{2}$
}

Received: 18 March 2019 / Accepted: 4 September 2019/Published online: 11 November 2019

(C) The Author(s) 2019

\begin{abstract}
The primary objective of the paper was the determination of the atmospheric circulation favouring the occurrence of strong and very strong stress of the human organism due to heat stress in Poland. The paper was prepared based on data obtained from the Institute of Meteorology and Water Management - National Research Institute and the National Center for Environmental Prediction/National Center for Atmospheric Research (NCEP/NCAR). The criterion of extreme stress of the human organism adopted in the paper covered conditions in which the Universal Thermal Climate Index (UTCI) value was higher than $32^{\circ} \mathrm{C}$. The research showed a statistically significant increase in half of the analysed stations and an increasing tendency or no changes in the remaining stations. Moreover, after 1990 , conditions particularly strenuous for the organism were recorded (UTCI $>40^{\circ} \mathrm{C}$ ) over a major part of the territory of Poland. The occurrence of days with strong and very strong heat stress in Poland was related to the presence of high-pressure systems blocking zonal circulation. The research permitted the designation of three types in which the pressure field showed common features, but differed in the location of anticyclonic systems.
\end{abstract}

\section{Introduction}

The currently observed climate changes are among others manifested in increasingly frequent occurrence of extreme weather phenomena (IPCC 2013). They determine the occurrence of extreme biometeorological conditions that therefore affect human health and life. Due to the aforementioned changes, the issue has been the subject of numerous studies (Hajat et al. 2002; Gabriel and Endlicher 2011; Bobvos et al. 2015; Muthers et al. 2017; Sheridan and Allen 2018). Unfortunately, the papers usually discussed the effect of only one meteorological element, i.e. air temperature. Among currently applied indices, considering both the effect of meteorological conditions on the human organism and physiological processes, the Universal Thermal Climate Index (UTCI), with a history of already a dozen years, is increasingly popular. It

Arkadiusz M. Tomczyk

atomczyk@amu.edu.pl

1 Department of Climatology, Institute of Physical Geography and Environmental Planning, Adam Mickiewicz University, B. Krygowskiego 10, 61-680 Poznań, Poland

2 Department of Meteorology and Climatology, Faculty of Oceanography and Geography, University of Gdańsk, Gdańsk, Poland was developed based on the advanced Fiala multinode model of human heat transfer and temperature regulation (Fiala et al. 1999; Fiala et al. 2001). The model considers both heat transfer inside the human body and on its surface and physiological thermoregulation processes. The UTCI permits the assessment of the intensity of physiological heat stress the human organism is subject to during striving for the maintenance of thermal equilibrium in different conditions of the surroundings, with consideration of thermal insulation properties of clothing (Havenith et al. 2011; Psikuta et al. 2012). The UTCI is expressed as equivalent air temperature in which in reference conditions the basic physiological parameters of the organism would adopt the same values as in actual conditions. It is a single-dimensional value reflecting responses of the organism to multidimensionally described meteorological and physiological information (Błażejczyk et al. 2012; Bröde et al. 2012).

The UTCI is an index frequently applied around the globe in the implementation of different research objectives. It concerned many countries, among others Germany (Matzarakis et al. 2014), Greece (Nastos and Matzarakis 2012; Bleta et al. 2014), Italy (Morabito et al. 2014), Hungary (Nemeth 2011), Czech Republic (Urban and Kyselý 2014), and the entire Europe (di Napoli et al. 2018), as well as Brazil (Bröde et al. 2013), China (Ge et al. 2016), Canada (Provençal et al. 2016), Iran (Mohammadi et al. 2018), or Tanzania (Ndetto and 
Matzarakis 2015). Research has also been conducted in Poland, both in a local scale (Milewski 2013; Błażejczyk et al. 2016), a scale of different regions (Mąkosza 2013; Kolendowicz et al. 2018), and of the entire country (Błażejczyk and Kunert 2011; Błażejczyk et al. 2018).

An important issue is the determination of the criterion of conditions of strong and very strong heat stress of the organism. Threshold values in particular categories of heat stress according to UTCI were determined based on critical levels of physiological responses (Bröde et al. 2012; Błażejczyk et al. 2013a). At UTCI of $30{ }^{\circ} \mathrm{C}$, the mean temperature of the skin on the body, face, and hands increases, and after 30-min exposure, sweating intensifies and skin moisture increases. At an index value of $32{ }^{\circ} \mathrm{C}$, the evaporation heat loss increases to more than $40 \mathrm{~W}$ already within $30 \mathrm{~min}$, and at $33^{\circ} \mathrm{C}$, the rate of sweating reaches more than $200 \mathrm{~g}$ per hour. UTCI values above $32{ }^{\circ} \mathrm{C}$ correspond to the categories of strong, very strong, or extreme heat stress according to the scale of assessment of heat stress. UTCI is a universal index and can be applied in different climate zones (Jendritzky et al. 2012; Błażejczyk et al. 2012). Considering the conditions of the climate of Poland (temperate), however, residents of the zone are probably more sensitive to heat stress, and the same class of stress can be perceived in a different way than by populations inhabiting warmer regions of the world. This is confirmed by differences in the occurrence of thermal comfort according to the PET index (Höppe 1999) in residents of Central Europe and south-east Asia evidenced by Lin and Matzarakis (2011). Considering the fact that the PET index shows considerable accordance with UTCI (Błażejczyk et al. 2012), heat stress with extreme intensity and its negative effects in residents of Central Europe can be presumed to occur already in conditions described by UTCI values lower than the threshold value of extreme heat stress equal to $46{ }^{\circ} \mathrm{C}$. Moreover, an increase in the mean daily mortality was determined in cities of different sizes in Poland in conditions of UTCI amounting to at least $32{ }^{\circ} \mathrm{C}$ (Błażejczyk et al. 2018). In the Czech Republic, neighbouring on Poland, an increase in mortality as a result of different analysed diseases was recorded, reaching even more than $17 \%$ on days when UTCI was equal or higher than the designated value of $90 \%$ distribution quantile, i.e. $22^{\circ} \mathrm{C}$ (Urban and Kyselý 2014). The determination of the value refers to some definitions of extreme conditions applied in the literature according to which an extreme weather phenomenon (in reference to high values of the phenomenon) occurs in a given area not more frequently than suggested by values of 90,95 , or $99 \%$ quantile of the probability density function estimated based on observation (IPCC 2014). Based on the above examples, conditions of UTCI higher than $32{ }^{\circ} \mathrm{C}$ can be considered extreme for Poland.

According to numerous studies, one of the most important factors determining weather and climate conditions at moderate latitudes is atmospheric circulation (Yarnal 1993). A particularly important property of the circulation over Europe is the occurrence of high-pressure systems, blocking zonal circulation (Tibaldi et al. 1997; Brunner et al. 2017). An evident increase in the frequency of blocking systems has been observed over Europe over the last decades (Leckebusch et al. 2008) and an increase in the stability of anticyclonic types of atmospheric circulation (Kysely and Domonkos 2006). In summer, these types of systems favour the occurrence of extreme thermal conditions in the form of heat waves, and in winter, cold waves (Ustrnul et al. 2010; Porębska and Zdunek 2013; Unkašević and Tošić 2015). Therefore, the effect of atmospheric circulation on thermal conditions, and particularly on the occurrence of thermal extremes in Poland, has been a subject of great interest for many years (Wibig et al. 2009; Tomczyk and Bednorz 2016; Wibig 2018; Tomczyk et al. 2019).

As evidenced above, air temperature is the primary component of the heat stress index UTCI describing biothermal conditions. Atmospheric circulation is therefore an important factor shaping the conditions, particularly in the case of conditions inducing strong stress for the human organism. The effect of atmospheric circulation on biothermal conditions in Poland determined by means of the UTCI has been usually analysed in a local scale, mainly in cities with different locations. The correlations were described by means of zonal and meridional circulation indices (Nowosad et al. 2013), in reference to defined types of anticyclonic, cyclonic, or indeterminate circulation (Rozbicka and Rozbicki 2017), selected circulation indices (Bartoszek et al. 2017), and through the designation of types of synoptic situations based on the pressure field at sea level and geopotential height of $500 \mathrm{hPa}$ (Kolendowicz et al. 2018). The effect of circulation on biothermal conditions throughout Poland in summer with the application of the canonical correlation analysis was investigated by Owczarek (2018).

Considering the importance of circulation in the development of weather conditions of the climate, as well as the occurring changes in the climatic system, manifested in increasingly frequent occurrence of extremely high air temperature values, the objectives of the paper were as follows: (1) analysis of the spatial and multiannual variability of occurrence of heat stress in the human organism in Poland and (2) determination of the character of atmospheric circulation favouring the occurrence of the aforementioned stress in Poland.

\section{Data and methods}

Extreme conditions causing stress for the organism were analysed with the application of the heat stress index UTCI, determined based on daily data from the period 1966-2015 from 40 meteorological stations in Poland, located in different physico-geographic regions (Fig. 1). Only high mountain 
stations were not included in the analysis. The study employed data series from 12:00 UTC: air temperature $\left({ }^{\circ} \mathrm{C}\right)$, relative humidity (\%), wind speed $(\mathrm{m} / \mathrm{s})$, and total cloudiness (octas). All data series are uniform and obtained from the data base of the Institute of Meteorology and Water Management National Research Institute. In accordance with the assumptions of the UTCI index, reference conditions were adopted, determined by the following meteorological characteristics: mean radiation temperature equal to the ambient temperature, wind speed at a height of $10 \mathrm{~m}$ above ground surface equal to $0.5 \mathrm{~m} / \mathrm{s}$, and water vapour pressure equivalent to $50 \%$ of relative humidity when the ambient temperature does not exceed $29{ }^{\circ} \mathrm{C}$ or equal to $20 \mathrm{hPa}$ at a temperature of more than $29^{\circ} \mathrm{C}$ (Bröde et al. 2012). The following reference physiological parameters were adopted: metabolic heat production while walking at a speed of $1.1 \mathrm{~m} / \mathrm{s}$ equal to $135 \mathrm{~W} / \mathrm{m}^{2}$ and thermal insulation properties of clothing in accordance with the current thermal and anemometric conditions.

In the paper, UTCI values were determined by means of the BioKlima 2.6 package (Błażejczyk and Błażejczyk 2006) with implemented computing algorithms with the application of the sixth degree exponential function (Błażejczyk et al. 2013a). The criterion of extreme stress at work was adopted as conditions in which the UTCI value was higher than $32^{\circ} \mathrm{C}$. Based on daily values of the index at 12:00 UTC, the annual, seasonal, and monthly frequency of occurrence of conditions of strong and very strong heat stress was determined in accordance with the scale of assessment of heat stress (Bröde et al. 2012). Values of $90 \%$ quantile of UTCI distribution in a given period were also determined. Moreover, cases of days were selected in which values of the UTCI exceeded the threshold of $40{ }^{\circ} \mathrm{C}$. The value corresponds to conditions in which the temperature gradient between the inside and surface of the human body decreases to less than $1{ }^{\circ} \mathrm{C}$ (Bröde et al. 2012; Błażejczyk et al. 2013a). Moreover, considering the occurring changes in the elements of the climate, the multiannual variability of the annual number of days with strong and very strong heat stress in Poland was analysed. The series trends were analysed with the application of the non-parametric Mann-Kendall test (Mann 1945; Wibig 2018) at a significance level of 0.05 .

For the purpose of determination of baric conditions favouring the occurrence of strong and very strong heat stress, daily values of sea level pressure (SLP), heights of isobaric surface $300 \mathrm{hPa}(\mathrm{z} 300 \mathrm{hPa})$, and air temperature on the isobaric surface $850 \mathrm{hPa}$ (T850) were applied. The data were obtained from the collections of the National Center for Environmental Prediction/National Center for Atmospheric Research (NCEP/NCAR) Reanalysis (Kalnay et al. 1996) available in the archives of NOAA ESRL PSD (Earth System Research Laboratory Physical Science Division). The selection of the level of $300 \mathrm{hPa}$ was made based on

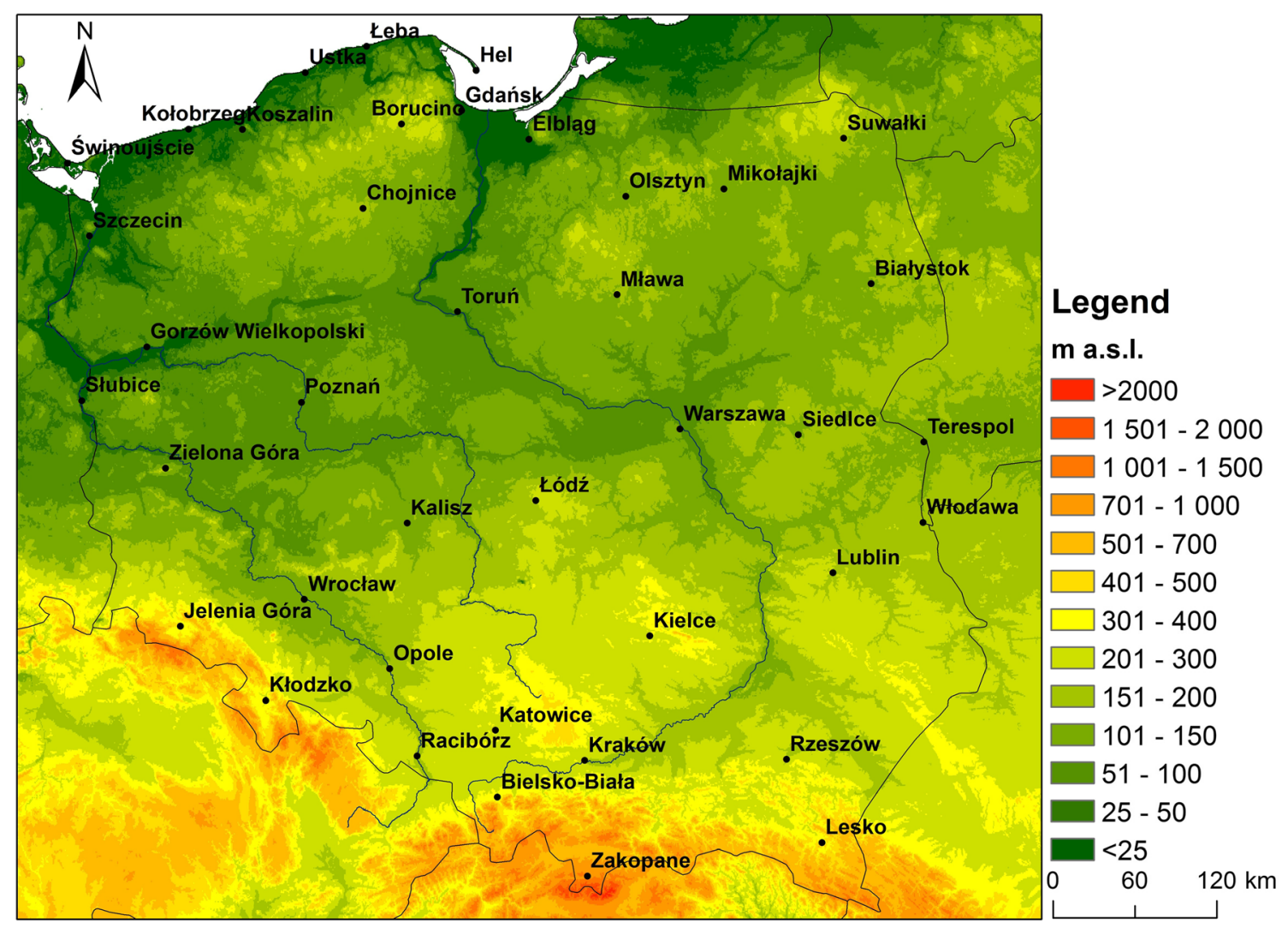

Fig. 1 Location of meteorological stations 
previously published study results, evidencing that the greatest anomalies of geopotential heights are recorded in the upper troposphere (Chen et al. 2017; Tomczyk 2018). Moreover, the level is commonly used in synoptics (WMO 2010). Bednorz et al. (2018a) also evidenced a strong correlation between mean daily, maximum, minimum air temperature, and geopotential height in the upper troposphere.

Based on the above data, average maps of SLP and $\mathrm{z} 300 \mathrm{hPa}$ were prepared for all days with strong or very strong heat stress. Then, the characteristics were supplemented by maps of anomalies of SLP, z300 hPa, and T850. The anomalies were calculated as the difference between the mean value of each of the above elements on a particular day and its mean value on a given day in the analysed multiannual. At the next stage, circulation types were designated through grouping particular days in terms of SLP values, with the application of the minimum variance method known as the Ward method (Ward 1963). The method is based on Euclidean distances and involves combining two clusters $\mathrm{A}$ and $\mathrm{B}$ which after combining into a single cluster provide the minimum sum of square deviations of all objects from the centre of gravity of the resulting cluster (Ward 1963; Bednorz 2009). The above grouping was performed based on standardized SLP values, introduced for the purpose of equalizing the seasonal variability with simultaneous maintenance of the intensity of the pressure field (Esteban et al. 2005). The Ward method is often applied in climatology, e.g. in the designation of seasons and climatic regions, and designation of weather types (Bednorz et al. 2018b; Tomczyk 2018). Then, for the designated types of circulation, maps of mean SLP and z300 hPa and maps of their anomalies, as well as anomalies of T850, were prepared. Moreover, similar maps were prepared for selected days with UTCI values above $40{ }^{\circ} \mathrm{C}$.

\section{Results}

The highest UTCI values that occurred in the analysed stations varied from $37.2{ }^{\circ} \mathrm{C}$ in the foothills of the Tatra Mountains to $43.1{ }^{\circ} \mathrm{C}$ in station Stubice in the west of the country. The values suggest that in the analysed multiannual, no conditions of extreme heat stress according to the scale of assessment of UTCI occurred in Poland. Values of $90 \%$ quantile of empirical distribution of UTCI values at 12:00 UTC varied in the analysed multiannual from below $23{ }^{\circ} \mathrm{C}$ at the coast to more than $26{ }^{\circ} \mathrm{C}$ in some regions of south Poland. Therefore, in the exclusively statistical approach, due to the scarcity of occurrence (IPCC 2014), even conditions of lack of heat stress or moderate heat stress according to the scale of assessment of UTCI can be sometimes treated as an extreme phenomenon.

The most regular course of isolines of the number of days with strong and very strong heat stress in the years 1966-2015 was observed in the northern part of Poland. The lowest number of days occurred at the coast. It did not exceed 4 days in a year and 5 days in the summer season (Fig. 2a). The mitigating effect of the waters of the Baltic Sea on biothermal conditions was observed in the region. The frequency of occurrence of the analysed phenomenon increased southwards to more than 10 days in a year, and more than 7 days in summer, and locally even to more than 9 days. The highest mean monthly frequency of occurrence was characteristic of July-locally up to 4 days, e.g. in Opole (Figs. 1 and 2b). In August, the number of days reaches approximately 3 . The highest frequency of occurrence of strong and very strong heat stress was observed in the south and west of Poland. Such spatial differentiation results from the variability of inflow of solar radiation, location towards the Baltic Sea, and local geographical conditions (e.g. altitude, river valleys). Properties of the inflowing air masses are crucial. The exact characteristics of the frequency of types of air masses in different regions of Poland were provided by, among others, Marsz and Styszyńska (2000), Kierkło (2012), and Kotas et al. (2013).

In the multiannual course, the highest number of days with strong or very strong heat stress at 12:00 UTC occurred in the highest number of stations in 1994. In 23 stations, except for seaside stations and those of the foothills of the Tatra Mountains, from 10 to 25 such cases were recorded. The situation was similar in 2015, when the annual number of such days was the highest in 15 stations and varied from 10 to 27 . The analysis of the temporal variability of the annual number of the analysed days suggests that half of the considered multiannual series is characterized by an increasing, statistically significant trend (Fig. 3). The fastest rate of increase, by approximately 2 days per decade, was determined in south and south-east Poland (e.g. in Kraków, Fig. 4a). The areas are also characterized by high frequency of occurrence of strong and very strong heat stress, exceeding approximately 7 days in a year and equalling approximately 3 days in July and in August. The biothermal conditions were subject to the greatest transformation over the analysed multiannual there. The annual number of days with strong and very strong heat stress increased in particular stations by 5 to even 11 days. The remaining identified trends, in 15 stations, point to an increase in the number of analysed days by approximately 1 day per decade (e.g. in Warszawa, Fig. 4b). In half of the stations located in the north part of Poland and in south-west Poland and in the foothills of the Tatra Mountains, no changes in the analysed number of days were determined, or trends were no statistically significant. Only in seaside stations, no changes were recorded in the occurrence of strong heat stress in accordance with changes of thermal conditions, which can point to the mitigating role of anemometric conditions in shaping heat stress in human organism in the coastal zone of the Baltic Sea.

The occurrence of days with strong and very strong heat stress in the study period was on average related to the 

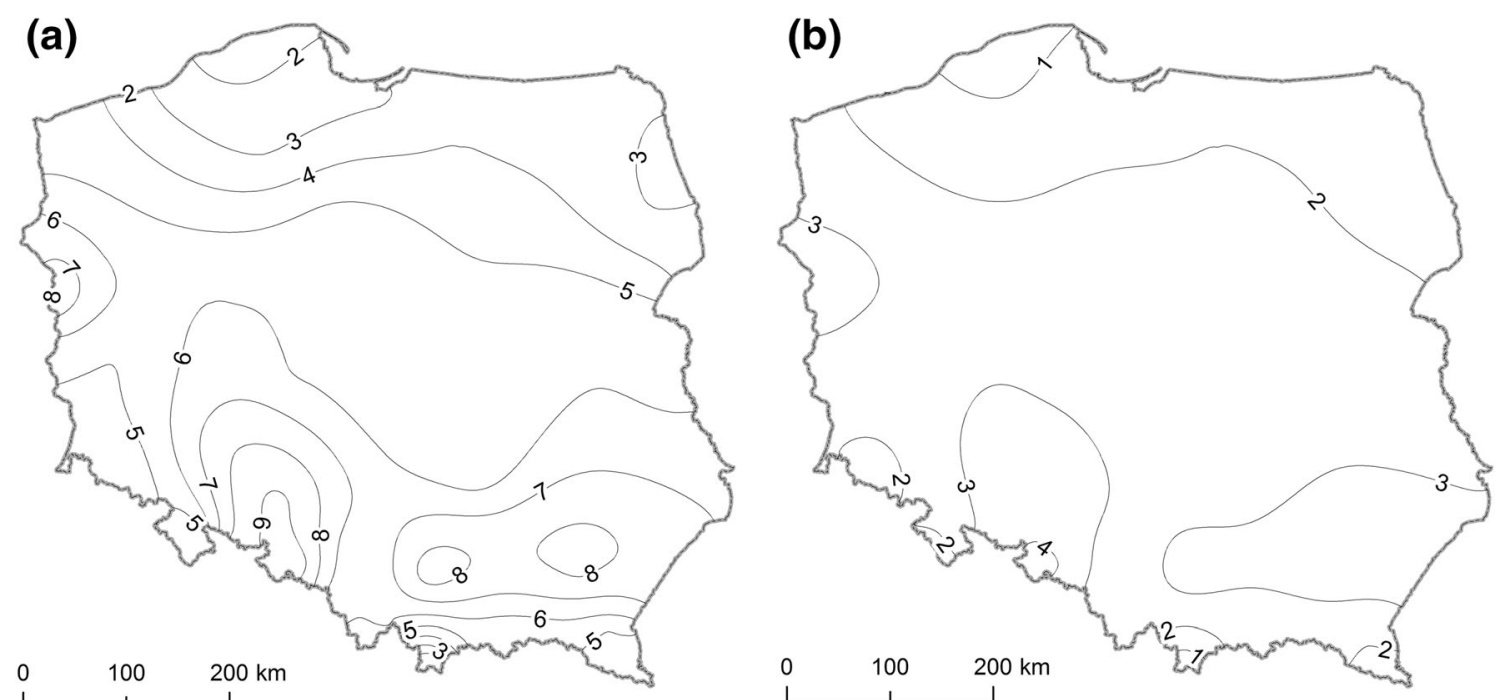

Fig. 2 Mean number of days with strong and very strong heat stress acc. to UTCI in Poland in JJA (a) and July (b), 1966-2015

persistence of an extensive high-pressure ridge over the EuroAtlantic sector, related to the Azores High (Fig. 5). Within the system, a local high developed over central-east Europe (> $1018 \mathrm{hPa}$ ). The prevailing part of the continent was dominated by the described baric system, as suggested by SLP anomalies. In the centre of the anomalies, SLP was higher by more than $4 \mathrm{hPa}$ than on average, and over the study area, anomalies varied from $0.5 \mathrm{hPa}$ in the west to $>3.5 \mathrm{hPa}$ in the north-east. Simultaneously, over the western areas of the continent and the Atlantic Ocean, negative SLP anomalies were recorded, amounting to $<-2 \mathrm{hPa}$ in the centre. On the analysed days over Central Europe, the isobaric surface $300 \mathrm{hPa}$ persisted considerably higher than on average in the analysed

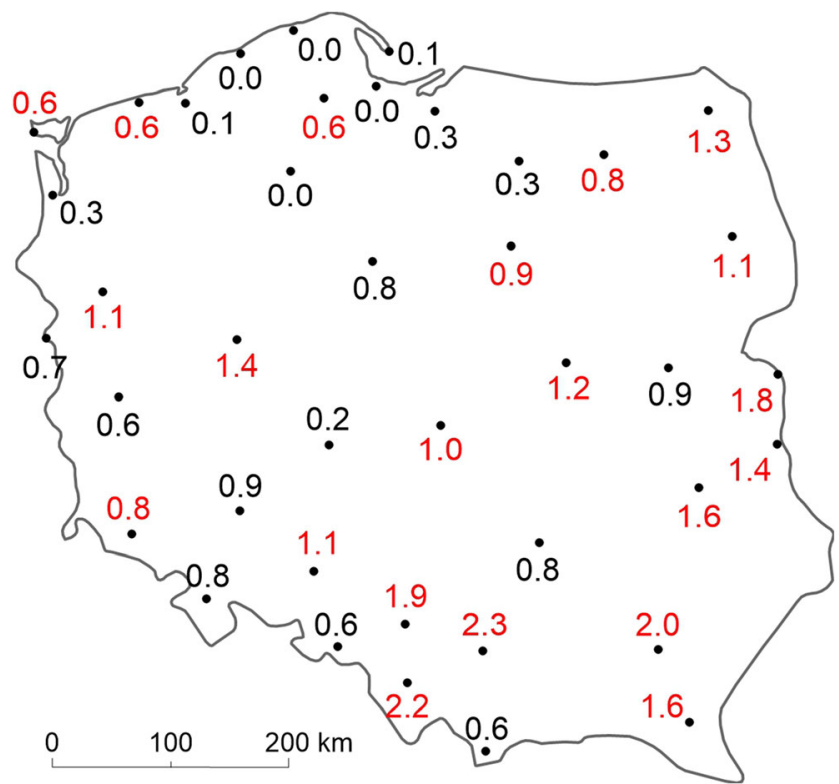

Fig. 3 Trend coefficients of mean annual number of days with strong and very strong heat stress (trend, day decade ${ }^{-1}$ ) in Poland, 1966-2015. Statistically significant (at 0.05 level) values are in red multiannual. This is suggested by isohips z300 hPa, evidently bent towards the north over this part of the continent, as well as positive height anomalies. The centre of anomalies persisted over north Poland and south Baltic Sea, where z300 hPa persisted $>160 \mathrm{~m}$ higher than on average. The described baric system caused advection of warm air masses, as suggested by positive anomalies of T850. The centre of the anomalies was located over south-west Poland $\left(>6{ }^{\circ} \mathrm{C}\right)$, and the course of isoanomalies suggests advection from the southwest.

Further detailed research on baric conditions led to the designation of three types of circulation favouring the occurrence of days with strong and very strong heat stress (Fig. 6a). In type 1 (with 132 days), similarly as in general conditions determined for all days with strong and very strong heat stress over the Euro-Atlantic sector, a high-pressure ridge persisted with developed local high over west Russia (> 1019 hPa). On the analysed days, over a major part of the continent, SLP was higher than average in the study period. Over the analysed area, the anomalies varied from $0 \mathrm{hPa}$ in south-west to > $3.5 \mathrm{hPa}$ in north-east, and in the centre of the system, they were $>6 \mathrm{hPa}$. Simultaneously, over western regions of the continent, SLP was lower than average. In type 2 (with 123 days), the continent was under the influence of a highpressure ridge, similarly as in type 1 , although the system was shifted towards the north-west. Within the system, an extensive high-pressure system developed with a centre over the Scandinavian Peninsula $(>1019 \mathrm{hPa})$. The area of positive SLP anomalies extended from the south-east to the northwest. Over the analysed area, SLP was higher than average, from $1 \mathrm{hPa}$ in the south-west to $5 \mathrm{hPa}$ in the north-east, and in the centre of the system $>7 \mathrm{hPa}$. In type 3 (with 121 days), the high-pressure ridge was shifted southwards in relation to types 1 and 2. The centre of the local high persisted over Romania (>1019 hPa). Simultaneously, north and north-west Europe 
(a)

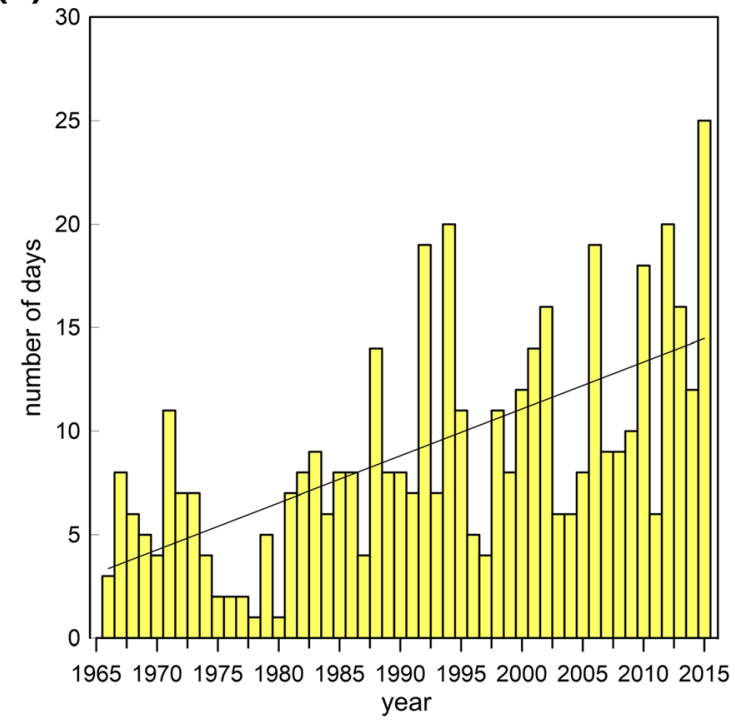

(b)

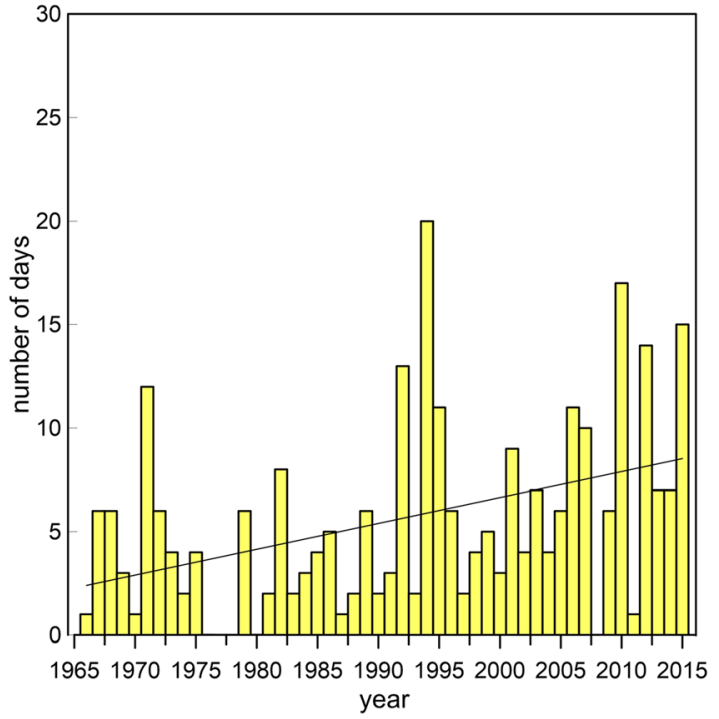

Fig. 4 Multiannual variability of annual number of days with strong or very strong heat stress according to UTCI in Kraków (a) and Warszawa (b), 1966-2015. Solid lines represent respective trends

was within the range of a low-pressure system, with a centre located south-east of Iceland (1005 hPa). In this type, the Euro-Atlantic sector was under the influence of two systems of SLP anomalies, negative in the west and positive in southeast. Over the study area, SLP anomalies varied from $<0 \mathrm{hPa}$ in the west to $>3.5 \mathrm{hPa}$ in south-east.

In each of the designated types, during the occurrence of days with strong and very strong heat stress, isohips of the isobaric surface $300 \mathrm{hPa}$ over Central Europe were bent northwards, developing its evident elevation (Fig. 6b). On the analysed days over a major part of the Euro-Atlantic sector, positive anomalies of $\mathrm{z} 300 \mathrm{hPa}$ were recorded, with the centre in types 1 and 2 covering the northern regions of the study area, and in type 3 , the centre of the anomalies covered the area of the entire country. In each type, anomalies in the centre were $>160 \mathrm{~m}$. Simultaneously over the Atlantic Ocean, (a)

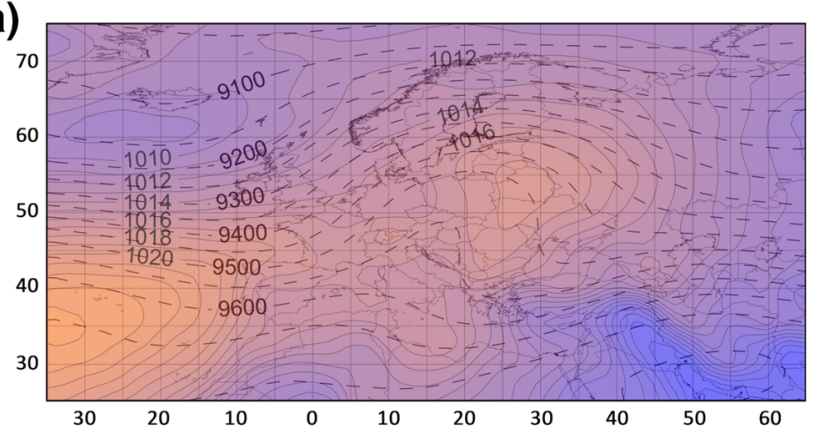

(b)

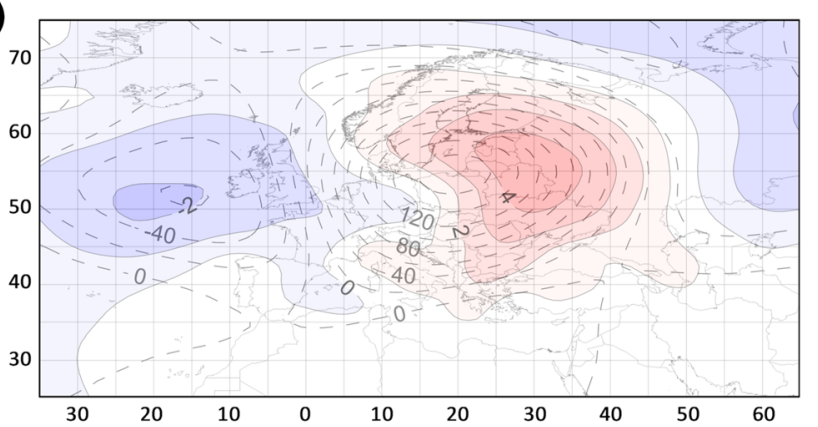

(c)

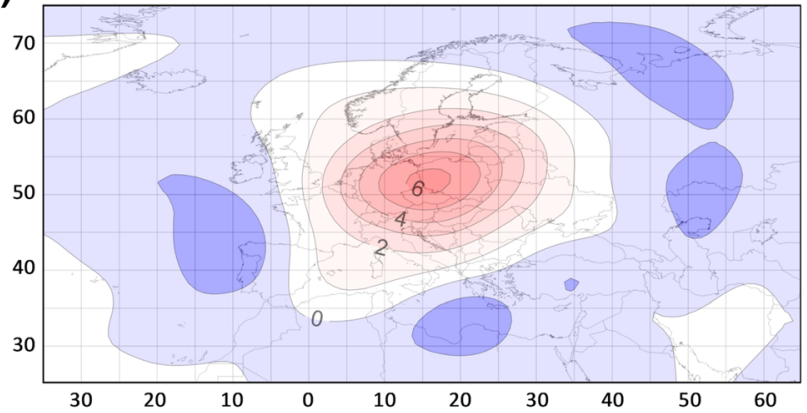

Fig. 5 Mean SLP [in hPa] (colour scale) and z300 hPa [in gpm] (dotted line) (a); anomalies of SLP [in hPa] (colour scale) and z300 hPa [in m] (dotted line) (b); and anomalies of $\mathrm{T} 850$ [in $\left.{ }^{\circ} \mathrm{C}\right]$ (c) for days with strong and very strong heat stress 


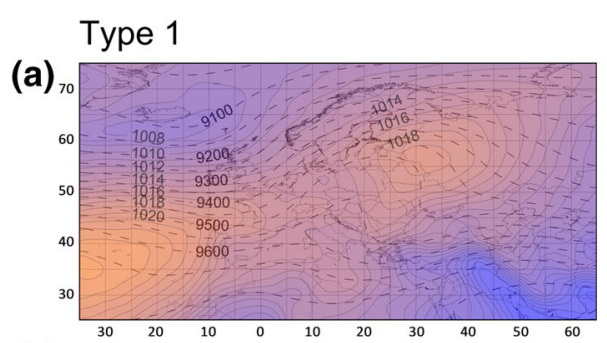

\section{Type 2}

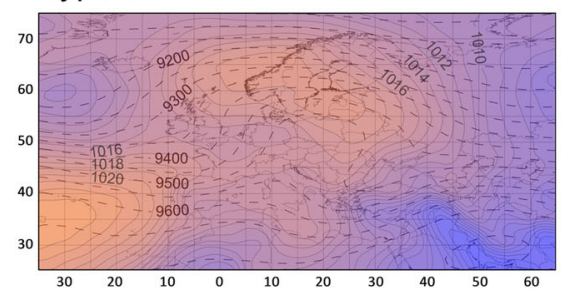

(b)

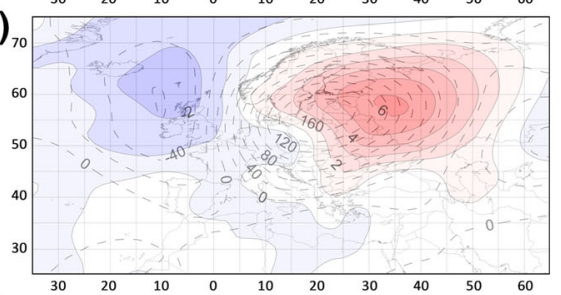

(c)

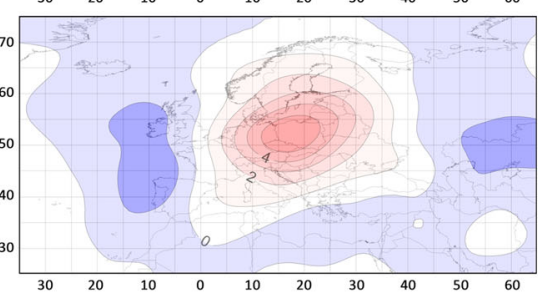

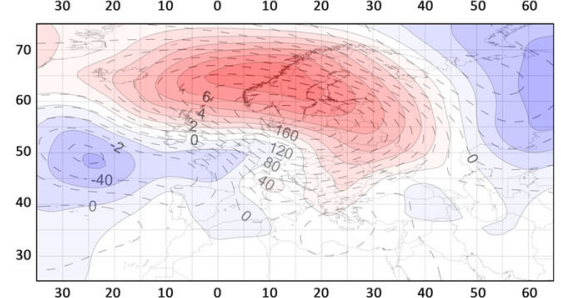

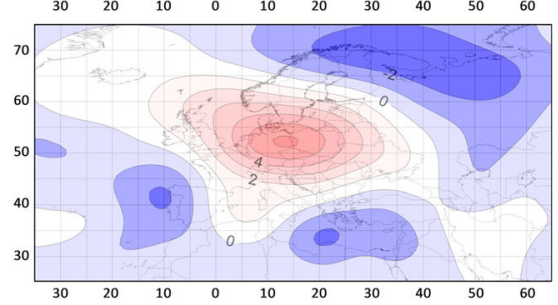

Type 3
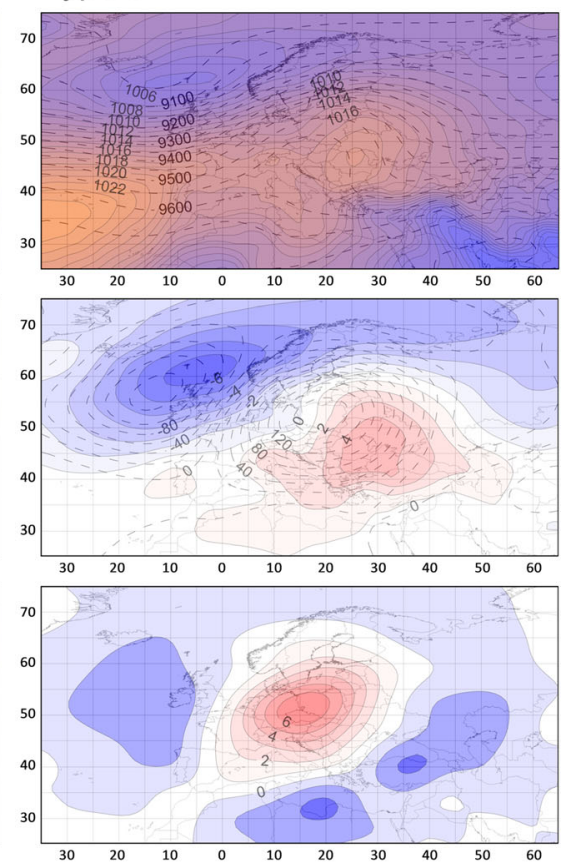

Fig. 6 Mean SLP [in hPa] (colour scale) and z300 hPa [in gpm] (dotted line) (a); SLP anomalies [in hPa] (colour scale) and z300 hPa [in m] (dotted line) (b); and anomalies of $\mathrm{T} 850$ [in $\left.{ }^{\circ} \mathrm{C}\right]$ (c) for the designated circulation types

z300 hPa persisted lower than on average by a maximum of $>120 \mathrm{~m}$ in type 3 .

In addition to advection of warm air masses, the described baric conditions could cause strong inflow of solar radiation to the ground at low cloudiness or in its absence, which is characteristic of anticyclonic weather (Fig. 6c). The increase in cloud cover can be usually caused by the intensification of convection. In type 1 , the occurrence of days with strong and very strong heat stress was related to the advection of air masses from the southern sector, in type 2 from the south-eastern sector, and in type 3 from the south-western sector. Values of anomalies in the centre of the system varied from $5^{\circ} \mathrm{C}$ in type 1 to $7{ }^{\circ} \mathrm{C}$ in type 3.

\subsection{Case studies (10.08.1992, 31.07.1994)}

In the analysed period, days can be designated with conditions particularly strenuous for the organism covering the majority of the territory of Poland. They all occurred after 1990. On 10 August 1992 and 31 July 1994, UTCI values of at least $40{ }^{\circ} \mathrm{C}$ occurred in $20 \%$ of stations (Fig. 7). In the first case, the highest UTCI values were recorded in north and north-west Poland, and in the second case in west and south-west Poland. The cases were related to the occurrence of heat waves. The most strenuous ones also include biothermal conditions of 9 August 1992, 26-31 July 1994, 21 July 1998, 16 and 17 July 2007, 13 August 2008, and 8 August 2015. The UTCI values of at least $40{ }^{\circ} \mathrm{C}$ occurred in 3 to 7 stations.
A detailed analysis of baric conditions was also performed for selected days on which UTCI values were $\geq 40^{\circ} \mathrm{C}$ over a major part of the study area (Fig. 8). On the first of the analysed days, the high-pressure system persisted over east Europe (>1019 hPa) with simultaneous persistence of lowpressure systems over north Europe and the Atlantic Ocean. Negative SLP anomalies were recorded over a major part of the continent and ocean, and positive anomalies over east and south Europe. On the second of the analysed days, the highpressure system persisted over north Europe (>1022 hPa), and low-pressure systems predominated over the ocean and west Europe. Positive anomalies particularly covered the area of north and east Europe. Similarly as in the case of total conditions and in the designated circulation types over Central Europe, isohips of isobaric surface were evidently bent northwards. On the analysed days, considerably higher persistence of z300 hPa than on average was observed, and in the centre of systems, anomalies of $>200$ m were determined. On the first day, the centre of the anomalies was located over Lithuania, and on the second one over the Norwegian Sea. In the case of both days, the study area was within the range of positive anomalies, oscillating around 140 $220 \mathrm{~m}$ and $80-150 \mathrm{~m}$, respectively. Positive anomalies suggest the presence of warm air masses, as also confirmed by anomalies of T850. In the case of both days, advection of tropical air masses from the southern sector occurred. The values of anomalies suggest that on the first day, air masses were warmer, but on the second day, warm air masses covered a larger area. 

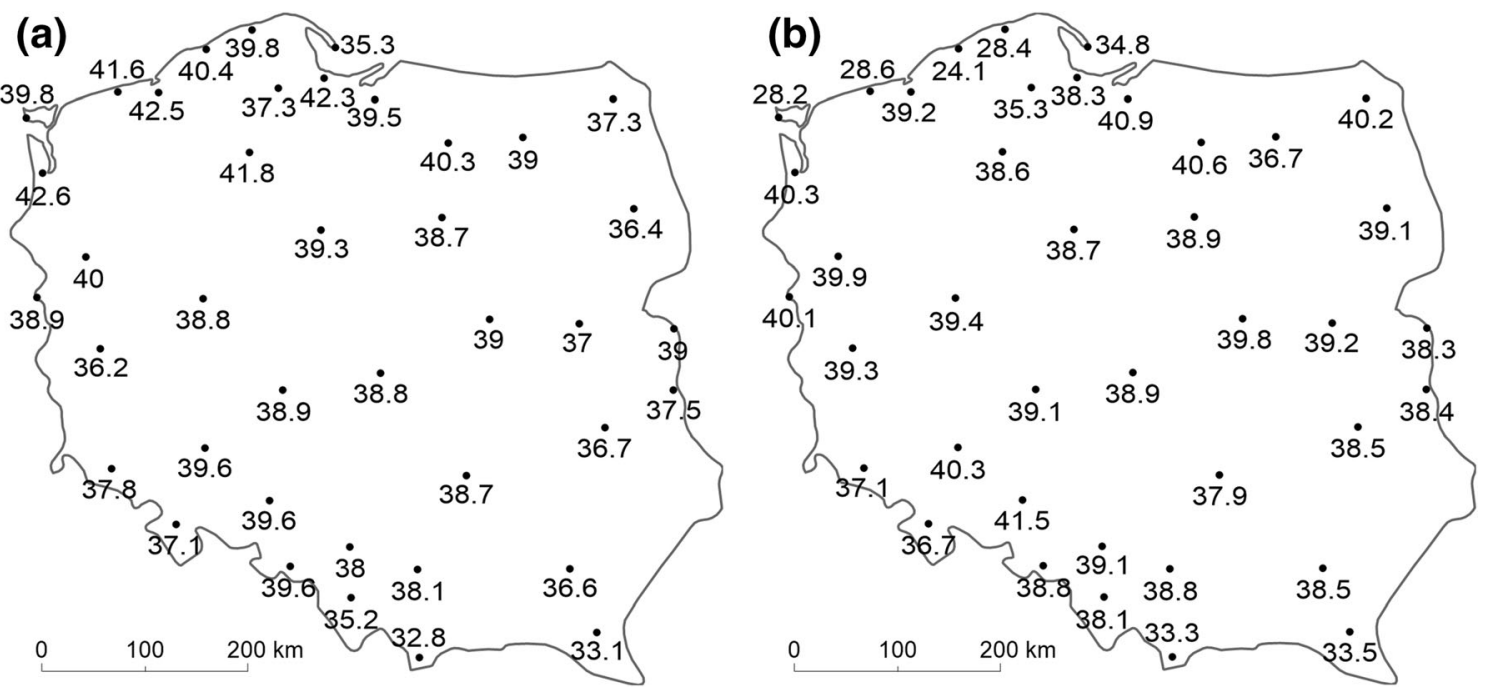

Fig. 7 UTCI values $\left({ }^{\circ} \mathrm{C}\right)$ on selected days: 10 August 1992 (a) and 31 July 1994 (b) in Poland

\subsubsection{2}

(a)

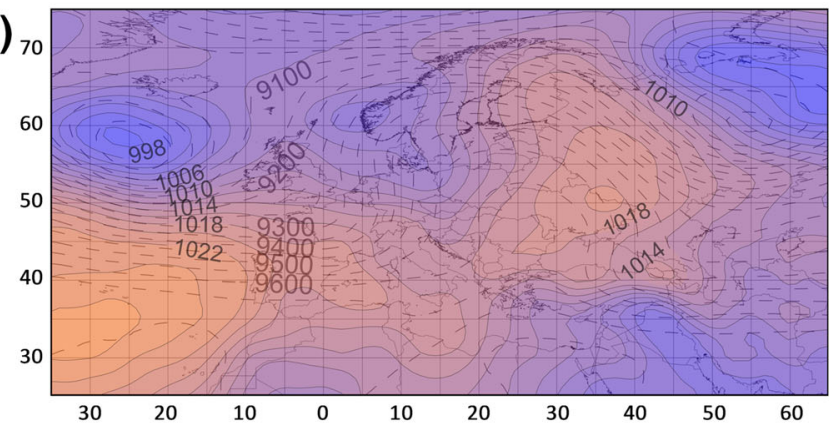

(b)

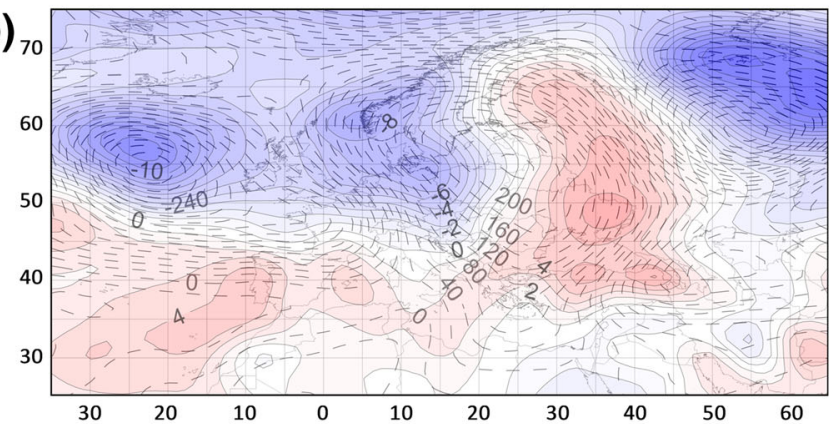

(c)

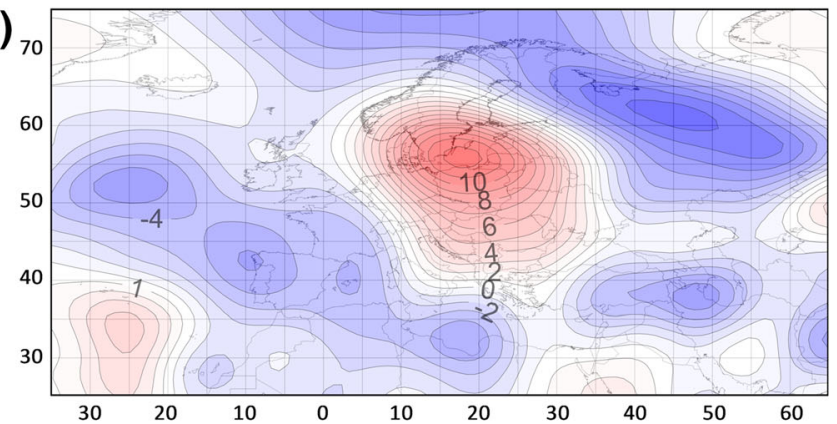

31.07.1994
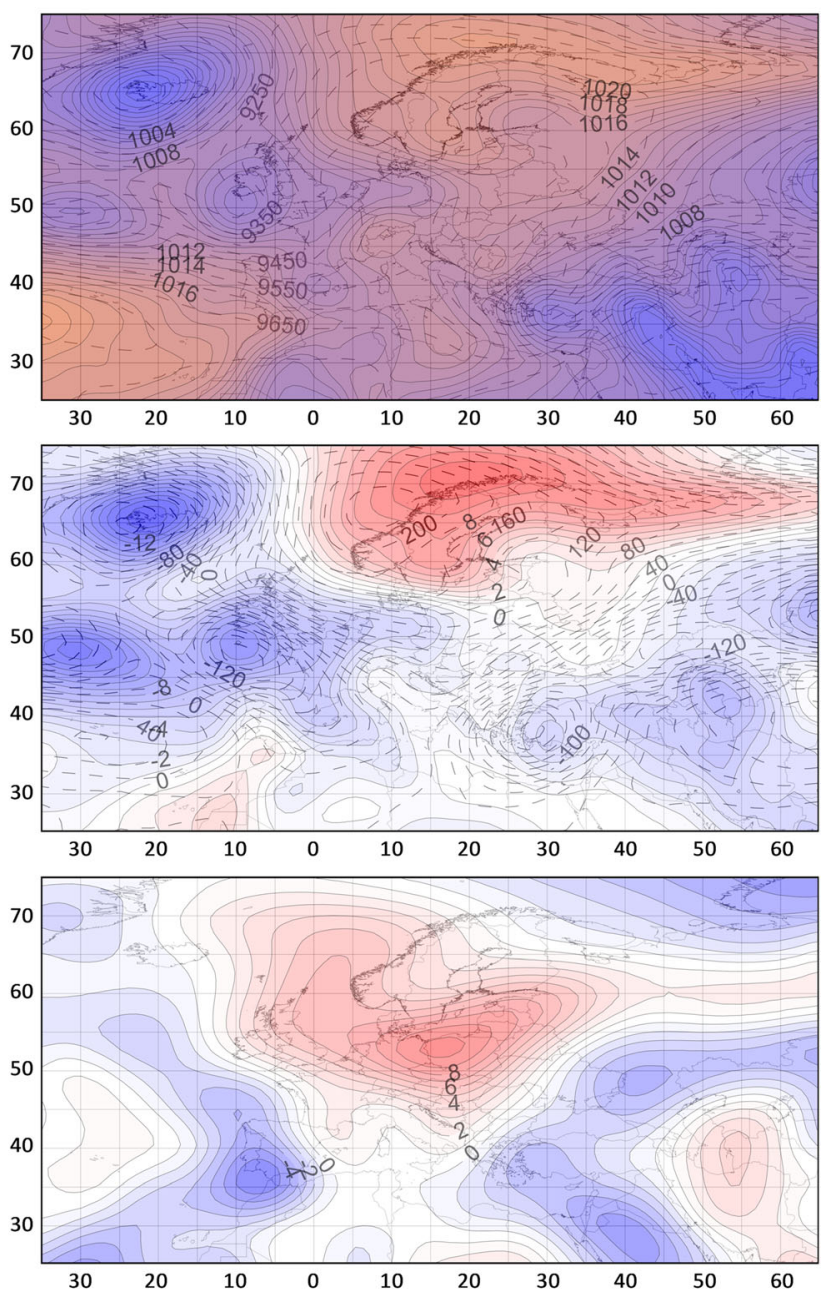

Fig. 8 Mean SLP [in hPa] (colour scale) and z300 hPa [in gpm] (dotted line) (a); SLP anomalies [in hPa] (colour scale) and z300 hPa [in m] (dotted line) (b); and anomalies of $\mathrm{T} 850\left[\right.$ in $\left.{ }^{\circ} \mathrm{C}\right]$ (c) for selected days 


\section{Discussion and summary}

The primary features of spatial variability of occurrence of strong and very strong heat stress according to the UTCI in Poland described in the paper are in line with previous studies related to bioclimatic conditions in Europe and Poland. Heat stress occurrence in Europe in summer show a latitude gradient, with UTCI values generally increasing towards the south. It reflects the general relationship between heat load and insolation (Di Napoli et al. 2018). While maximum UTCI values above $40{ }^{\circ} \mathrm{C}$ in summer are not differentiated spatially across Central Europe, the frequency of occurrence of strong and very strong heat stress is diversified (Błażejczyk et al. 2015). Mean number of days with strong and very strong heat stress in summer determined based on meteorological data from the period 1991-2000 in Poland is from approximately 1 day at the coast to around 4 days in Warszawa (in the central part of Poland), whereas in Prague and Budapest, the number of such days is approximately 9 and 20, respectively (Błażejczyk et al. 2015). According to results of the present work, referring to a longer period, an average of one more day with such stress occurs in Warszawa (approximately 5 days) as well as in coastal stations (approximately 2 days). The spatial variability of the occurrence of strong and very strong heat stress in Poland described in the present paper refers to the variability of occurrence of high air temperature. An average of 10 to 14 hot days (when maximum air temperature exceeds $25^{\circ} \mathrm{C}$ ) was recorded at the coast, approximately 15 days more in central Poland, and even 30 days more in south-west and south-east Poland (Wibig et al. 2009; Owczarek and Filipiak 2016). Nonetheless, strong and very strong heat stress can be most often evidence of the occurrence of sweltering days (days with maximum air temperature of at least $30^{\circ} \mathrm{C}$ ) and heat waves. Sweltering days occur once or twice a year at the coast and in north-east Poland. In the remaining area, such days are recorded 4 to 10 times a year on average (Owczarek and Filipiak 2016; Graczyk et al. 2017). The annual number of days with strong and very strong heat stress obtained in the present work is similar, but the number of sweltering days can be about 12 days lower on particular stations. It suggests the influence of air humidity on heat stress intensity. Air humidity related to high air temperature indicates an increase in UTCI with increasing humidity (Bröde et al. 2012; Kampmann et al. 2012). It favours sultriness and limits evaporative heat lost from the human body. Błażejczyk and Błażejczyk (2014) used different simulated meteorological variables to calculate the UTCI for standard meteorological station. In sunny weather with air temperature of $30^{\circ} \mathrm{C}$, a noticeable intensification of heat stress is observed with an increase of relative humidity values, especially when wind speed is low. It can be modified by different local conditions. The occurrence of extremely high vapour content in the air in summer in Europe is not significantly connected with a dominant advection direction. Therefore, convection processes play a more important role than horizontal moisture flux (Zveryaev 2004; Zveryaev et al. 2008; Wypych et al. 2018). The problem, however, was usually examined in the context of heavy precipitation. The effect of humidity on heat stress was considered most often in relation to warm-humid climate, such as that in Ecuador (Johansson et al. 2018) or Tanzania (Ndetto and Matzarakis 2015). Intensive sultriness leading to overheating risk according to heat stress index (HSI) in Poland at 12:00 UTC can occur, on average, during less than 1 day to 9 days in a year (Błażejczyk and Kunert 2011). Strong or very strong heat stress in Poland can occur in a particular station as a single case or can be related to the occurrence of heat waves. Two cases of the strongest heat stress described in the present paper were related to the occurrence of particularly severe heat waves. These results confirmed the occurrence of extremely high air temperature in central and east Europe (Kysely 2010; Kažys et al. 2011; Shevchenko et al. 2013). The summer of 1994 was more extreme over Central Europe than the well-known summers of 2003 and 2010 (Lhotka and Kyselý 2015). Almost throughout Poland, more than 16 sweltering days were recorded. In the south-west of the country, the number of such days exceeded 20 (Graczyk et al. 2017). The longest annual spell of consecutive sweltering days consisted of more than 10 days across Poland (Wibig 2012), and the heat wave lasting ceaselessly for at least 17 days was observed in 12 out of 24 stations considered in the research by Wibig (2018). In the Czech Republic, the longest heat wave lasted for 18 days (Urban et al. 2017). More than 20 sweltering days were also observed in Poland in 1992, but over a smaller area (Graczyk et al. 2017). Heat waves in Poland occur the most frequently in the central part of west Poland and the least frequently at the coast and in the mountains (Wibig 2018). This is confirmed by results of the present paper, but strong and very strong heat stress also frequently occur in south and south-east Poland.

The most important pattern of variability of occurrence of strong and very strong heat stress in Poland presented in the paper is its statistically significant increase in half of the analysed stations, whereas no downward trend was observed anywhere. A similar direction of changes was evidenced in papers published to date concerning multiannual variability of bioclimatic conditions, although importantly, the research did not cover the entire country. A twice higher frequency of occurrence of strong and very strong heat stress in the 1990s than in the 1950s was observed in three stations in Poland, and an increase in mean monthly UTCI values from the 1950s to 2000 was evidenced by Okoniewska and Więclaw (2013). In south-east Poland in the 1980s, very strong heat stress at 12:00 UTC occurred not more than twice in a year, and after 2005 already five times (Nowosad et al. 2013). Results of the present paper show approximately 6 to 7 days. According to Błażejczyk et al. (2013b), from 2000 to 2100 , an increase in the number of days with heat stress according to UTCI in 
Warszawa is predicted at a rate of 0.9 per decade. The rate of the increase evidenced in this paper is even higher (in Warszawa more than 1 day per decade), but it only concerns the least strong heat stress category. Research on the variability of biothermal conditions at the southern coast of the Baltic Sea from 1981 to 2010 showed a trend of an increase in the number of days with strong heat stress by 3 to 6 days per 10 years (Półrolniczak et al. 2016) and with moderate heat stress during 1981-2014 by 2 to 4 days per 10 years (Kolendowicz et al. 2018) in the central part of the coast. Moreover, at the coast, a systematic increase in mean monthly UTCI values was evidenced in all summer months (Kažys and Malūnavičiūtè 2015). Differences in the rate of increase may result from the different time scales used in the present work. Over the majority of the territory of Poland, the determined changes are in accordance with changes in the number of hot days and sweltering days in Poland, increasing at a rate from 1 to 3 days per 10 years and from 1 to 2 days per 10 years, respectively (Owczarek and Filipiak 2016; Graczyk et al. 2017). The rate of growth has increased since the 1980 s compared to trends related to longer periods (Wibig et al. 2009). An explicit increase was also detected in the frequency of summer heat waves as well as in their duration in Europe (Meehl and Tebaldi 2004; Della-Marta et al. 2007). A statistically significant increase in the number of days with heat waves in the years 1951-2015 was shown for $60 \%$ of considered stations in Poland (Wibig 2018). The spatial extent of these changes is slightly larger when compared with results of the present paper related to changes in the occurrence of strong and very strong heat stress. Changes in biothermal conditions towards the intensification of heat stress were also evidenced in reference to other European countries, e.g. Hungary (Nemeth 2011) or Romania (Dobrinescu et al. 2015), as well as distant regions, e.g. China (Kong et al. 2018) or Hong Kong (Cheung and Hart 2014).

The research showed that the occurrence of days with strong and very strong heat stress in Poland was related to the presence of high-pressure systems blocking zonal circulation. In each of the designated types, the pressure field showed common features, but differed in the location of anticyclonic systems. The location and intensity of lows is suggested by positive SLP anomalies, determining the direction of advection of air masses. Positive anomalies of $\mathrm{z} 300 \mathrm{hPa}$ and $\mathrm{T} 850$ point to the persistence of warm air masses over this part of the continent. Similar results, pointing to the important role of meridional circulation in the development of heat stress, were obtained in earlier studies. It was evidenced that the occurrence of strong heat stress at the southern coast of the Baltic Sea is determined by the advection of air masses from the south (Półrolniczak et al. 2016; Kolendowicz et al. 2018). The authors also pointed to the presence over the continent of a high-pressure ridge together with local highs or a strong high over north Europe. Nowosad et al.
(2013) evidenced a stronger correlation between UTCI and the meridional circulation index than zonal circulation index in south-east Poland from April to October. Bartoszek et al. (2017), analysing the circulation conditions of strong and very strong heat stress in south-east Poland, designated two types of anticyclonic circulation. The first one, favourable for southern inflow of very warm tropical air, is similar to a situation that appeared in the present work in type 3, but with lower values of SLP anomalies. The second one is similar to type 2 in the present work in term of causing advection of dry warm air masses from the east to west. Owczarek (2018) evidenced that air advection from the east or south-east, related to the centre of high pressure over north-east Europe or over south Scandinavia and Baltic, can cause even a dozen percent increase in the frequency of occurrence of heat stress according to UTCI in Poland. Circulation favouring weak eastern flow, intensified radiation, and still air conditions can consequently lead to an increase in the frequency of occurrence of heat stress by more than $10 \%$. Approximate baric conditions were also determined through the analysis of the circulation conditions of sweltering days and heat waves in Poland or Central Europe. Days with maximum air temperature of at least $30^{\circ} \mathrm{C}$ occur when pressure over central and east Europe is higher than normal, but the centre of positive SLP anomalies is located over east Poland (Wibig et al. 2009). General conditions determined for days with strong and very strong heat stress show the centre located a little eastwards. Three circulation types favourable for the occurrence of heat waves in Central Europe were determined by Tomczyk and Bednorz (2016). Heat waves were most often associated with a ridge of high pressure across Europe and high-pressure area over the Baltic Sea. Anticyclonic centre formed over the south-eastern part of Central Europe was also determined in the same work. Similar conditions favourable for strong and very strong heat stress were determined in the present paper in circulation types 2 and 3 . However, the third pattern connected with two wide baric centres of low pressure over most of the European continent and high over east Europe bringing warm air from south-west to Central Europe was not revealed in the present study. Circulation types conducive to heat waves in Central Europe were characterized by anticyclonic, southern, and eastern flow with warm air advection (Plavcová and Kyselý 2016). The occurrence of heat waves in south-east Poland connected with a high-pressure area east of Poland as well as the surface low-pressure gradient area over west and Central Europe were described by Bartoszek and Krzyżewska (2017). Wibig (2018) distinguished four typical situations favouring the development of heat waves in Poland. All these patterns are characterized by strong blocking determined by a persistent and widespread high-pressure system over the North Atlantic close to the Azores. The pattern with a high-pressure system expanded far north over the North Atlantic and a weak high-pressure ridge over Europe. The pattern with a well-developed Azorian High with a ridge spreading 
far to the north-east up to Russia as well as the pattern characterized by the presence of the high-pressure area centred over the Azores, and the second one with the centre over the Scandinavian Peninsula, linked by high-pressure ridge, seemed to be the most similar to that determined in the present work. The impact of persistent anticyclonic conditions on the heat wave in Europe was indicated among others in works of Black et al. (2004), Della-Marta et al. (2007), and GarciaHerrera et al. (2010). Moreover, it is worth remembering that the exact location and duration of heat waves are uncertain and largely controlled by the atmospheric circulation, especially at mid-latitudes (Shepherd 2014; Kornhuber et al. 2019). The occurrence of days with the most intensive heat stress was found to be related to the inflow of considerably warmer air masses than on average, as suggested by high positive anomalies of T850 (maximum $>11^{\circ} \mathrm{C}$ ). Earlier, it was evidenced that the occurrence of the warmest days during the selected heat waves was related to the advection of warm air masses, the range of which reached the isobaric level of $250 \mathrm{hPa}$ (Tomczyk et al. 2019). A similar range of positive anomalies of air temperature was determined in other numerous studies both from Europe (Tomczyk et al. 2017; Tomczyk 2018; Owczarek 2018) and China (Chen et al. 2017). Moreover, on the analysed days, much greater anomalies of SLP and $\mathrm{z} 300 \mathrm{hPa}$ were recorded than on average on days with strong heat stress. Considerably stronger baric systems were also revealed by analyses of examples of strong heat waves (Tomczyk and Sulikowska 2018; Tomczyk et al. 2019). The study results confirm the change in biometeorological conditions in Poland, manifested in increasingly frequent occurrence of extreme conditions. Moreover, they confirm the influence of upper tropospheric circulation on conditions in the lower atmosphere and next bioclimatic conditions. The obtained results encourage further research focusing on thorough investigation of the variability of biometeorological conditions in a day, particularly on days described as strongly biometeorologically strenuous.

Funding information This work was supported by the National Science Centre, Poland (grant number UMO-2017/24/C/ST10/00109).

Open Access This article is distributed under the terms of the Creative Commons Attribution 4.0 International License (http:// creativecommons.org/licenses/by/4.0/), which permits unrestricted use, distribution, and reproduction in any medium, provided you give appropriate credit to the original author(s) and the source, provide a link to the Creative Commons license, and indicate if changes were made.

\section{References}

Bartoszek K, Krzyżewska A (2017) The atmospheric circulation conditions of the occurrence of heatwaves in Lublin, Southeast Poland. Weather 72(6): 176-180

Bartoszek K, Wereski S, Krzyżewska A, Dobek M (2017) The influence of atmospheric circulation on bioclimatic conditions in Lublin (Poland). Bull Geogr Phys Geogr Ser 12:41-49
Bednorz E (2009) Wpływ sytuacji barycznych na występowanie pokrywy śnieżnej na obszarach nizinnych środkowej Europy. Wydawnictwo Naukowe Uniwersytetu im. Adama Mickiewicza, Poznań

Bednorz E, Czernecki B, Tomczyk AM, Półrolniczak M (2018a) If not NAO then what? - regional circulation patterns governing summer air temperatures in Poland. Theor Appl Climatol. https://doi.org/10. 1007/s00704-018-2562

Bednorz E, Czernecki B, Półrolniczak M, Tomczyk AM (2018b) Atmospheric forcing of upwelling along the southeastern Baltic coast. Baltica 31(1):73-85

Black E, Blackburn M, Harrison G, Hoskins B, Methven J (2004) Factors contributing to the summer 2003 European heat wave. Weather 59: 217-223

Błażejczyk K, Błażejczyk M (2006) BioKlima ver.2.6. Polish Academy of Sciences. www.igipz.pan.pl/bioklima.html. Accessed 01 Dec 2018

Błażejczyk K, Błażejczyk A (2014) Assessment of bioclimatic variability on regional and local scales in Central Europe using UTCI. Sci Ann Alexandru Ioan Cuza Univ IASI Geogr Ser 60(1):67-82

Błażejczyk K, Kunert A (2011) Bioklimatyczne uwarunkowania rekreacji i turystyki w Polsce (Bioclimatic principles of recreation and tourism in Poland). Monografie IGiPZ PAN 13, Warszawa (in Polish)

Błażejczyk K, Epstein Y, Jendritzky G, Staiger H, Tinz B (2012) Comparison of UTCI to selected thermal indices. Int $\mathrm{J}$ Biometeorol 56(3):515-535

Błażejczyk K, Jendritzky G, Bröde P, Fiala D, Havenith G, Epstein Y, Psikuta A, Kampmann B (2013a) An introduction to the Universal Thermal Climate Index (UTCI). Geogr Pol 86(1):5-10

Błażejczyk K, Idzikowska D, Błażejczyk A (2013b) Forecast changes for heat and cold stress in Warsaw in the 21st century, and their possible influence on mortality risk. Pap Glob Chang 20:47-62

Błażejczyk K, Baranowski J, Jendritzky G, Błażejczyk A, Bröde P, Fiala D (2015) Regional features of the bioclimate of Central and Southern Europe against the background of the Köppen-Geiger climate classification. Geogr Pol 88(3):439-453

Błażejczyk K, Kuchcik M, Dudek W, Kręcisz B, Błażejczyk A, Milewski P, Szmyd J, Pałczyński C (2016) Urban heat island and bioclimatic comfort in Warsaw. In: Musco F (ed) Counteracting urban heat island effects in a global climate change scenario. Springer International Publishing, Cham, pp 377-395

Błażejczyk A, Błażejczyk K, Baranowski J, Kuchcik M (2018) Heat stress mortality and desired adaptation responses of healthcare system in Poland. Int J Biometeorol 62(3):307-318

Bleta A, Nastos PT, Matzarakis A (2014) Assessment of bioclimatic conditions on Crete Island, Greece. Reg Environ Chang 14(5): 1967-1981

Bobvos J, Fazekas B, Páldy A (2015) Assessment of heat-related mortality in Budapest from 2000 to 2010 by different indicators. Időjárás 119(2):143-158

Bröde P, Fiala D, Blazejczyk K, Holmer I, Jendritzky G, Kampmann B, Tinz B, Havenith G (2012) Deriving the operational procedure for the Universal Thermal Climate Index (UTCI). Int J Biometeorol 56(3):481-449

Bröde P, Krüger EL, Fiala D (2013) UTCI: validation and practical application to the assessment of urban outdoor thermal comfort. Geogr Pol 86(1):11-20

Brunner L, Hegerl GC, Steiner AK (2017) Connecting atmospheric blocking to European temperature extremes in spring. J Clim 30(2):585-594

Chen Y, Hu Q, Yang Y, Qian W (2017) Anomaly based analysis of extreme heat waves in Eastern China during 1981-2013. Int J Climatol 37:509-523 
Cheung CSC, Hart MA (2014) Climate change and thermal comfort in Hong Kong. Int J Biometeorol 58:137-148. https://doi.org/10.1007/ s00484-012-0608-9

Della-Marta PM, Haylock MR, Luterbacher J, Wanner H (2007) Doubled length of western European summer heat waves since 1880. J Geophys Res 112:D15103

Di Napoli C, Pappenberger F, Cloke HL (2018) Assessing heat-related health risk in Europe via the Universal Thermal Climate Index (UTCI). Int J Biometeorol 62:1155-1165

Dobrinescu A, Busuioc A, Birsan MV, Dumitrescu A, Orzan A (2015) Changes in thermal discomfort indices in Romania and their connections with large-scale mechanisms. Clim Res 64:213-226

Esteban P, Jones PD, Martin-Vide J, Mases M (2005) Atmospheric circulation patterns related to heavy snowfall days in Andorra, Pyrenees. Int J Climatol 25:319-329

Fiala D, Lomas KJ, Stohrer M (1999) A computer model of human thermoregulation for a wide range of environmental conditions: the passive system. J Appl Physiol 87:1957-1972

Fiala D, Lomas KJ, Stohrer M (2001) Computer prediction of human thermoregulatory and temperature responses to a wide range of environmental conditions. Int J Biometeorol 45(3):143-159

Gabriel KMA, Endlicher WR (2011) Urban and rural mortality rates during heat waves in Berlin and Brandenburg, Germany. Environ Pollut 159:2044-2050

Garcia-Herrera R, Diaz J, Trigo RM, Luterbacher J, Fischer EM (2010) A review of the European summer heat wave of 2003. Crit Rev Environ Sci Technol 40:267-306

Ge Q, Kong Q, Xi J, Zheng J (2016) Application of UTCI in China from tourism perspective. Theor Appl Climatol 128(3-4):551-561

Graczyk D, Pińskwar I, Kundzewicz ZW, Hov Ø, Førland EJ, Szwed M, Choryński A (2017) The heat goes on-changes in indices of hot extremes in Poland. Theor Appl Climatol 129:459-471

Hajat S, Kovats RS, Atkinson RW, Haines A (2002) Impact of hot temperatures on death in London: a time series approach. J Epidemiol Community Health 56(5):367-337

Havenith G, Fiala D, Błazejczyk K, Richards M, Broede P, Holmér I, Rintamaki H, Benshabat Y, Jendritzky G (2011) The UTCI-clothing model. Int J Biometeorol 56(3):461-470

Höppe P (1999) The physiological equivalent temperature - a universal index for the biometeorological assessment of the thermal environment. Int J Biometeorol 43(2):71-75

IPCC (2013) In: Stocker TF, Qin D, Plattner G-K, Tignor M, Allen SK, Boschung J, Nauels A, Xia Y, Bex V, Midgley PM (eds) Climate change 2013: the physical science basis. Contribution of Working Group I to the Fifth Assessment Report of the Intergovernmental Panel on Climate Change. Cambridge University Press, Cambridge

IPCC (2014) Europe. In: Barros VR, Field CB, Dokken DJ, Mastrandrea MD, Mach KJ, Bilir TE, Chatterjee M, Ebi KL, Estrada YO, Genova RC, Girma B, Kissel ES, Levy AN, MacCracken S, Mastrandrea PR, White LL (eds) Climate change 2014: impacts, adaptation, and vulnerability, part B: regional aspects. Contribution of Working Group II to the Fifth Assessment Report of the Intergovernmental Panel on Climate Change. Cambridge University Press, Cambridge

Jendritzky G, de Dear R, Havenith G (2012) UTC — why another thermal index? Int J Biometeorol 56(3):421-428

Johansson E, Yahia MW, Arroyo Y, Bengs C (2018) Outdoor thermal comfort in public space in warm-humid Guayaquil, Ecuador. Int $\mathrm{J}$ Biometeorol 62:387-399. https://doi.org/10.1007/s00484-0171329-x

Kalnay E, Kanamitsu M, Kistler R, Collins W, Deaven D, Gandin L, Iredell M, Saha S, White G, Woolen J, Zhu Y, Chelliah M, Ebisuzaki W, Higgins W, Janowiak J, Mo KC, Ropelewski C, Wang J, Leetmaa A, Reynolds R, Jenne R, Joseph D (1996) The NCEP/NCAR 40-year reanalysis project. Bull Am Meteorol Soc 77: $437-470$
Kampmann B, Bröde P, Fiala D (2012) Physiological responses to temperature and humidity compared to the assessment by UTCI, WGBT and PHS. Int J Biometeorol 56(3):505-513

Kažys J, Malūnavičiūte I (2015) The evaluation of summer beaching conditions on the Baltic Sea coast using the UTCI index. Int J Clim Chang Impacts Resp 7:41-59

Kažys J, Stankūnavičius G, Rimkus E, Bukantis A, Valiukas D (2011) Long-range alternation of extreme high day and night temperatures in Lithuania. Baltica 24(2):71-82

Kierkło K (2012) Variability of air masses over Podlasie (NE Poland) in the years 2001-2010. Bull Geogr Phys Geogr Ser 5(1):97-113. https://doi.org/10.2478/v10250-012-0006-5

Kolendowicz L, Półrolniczak M, Szyga-Pluta K, Bednorz E (2018) Human-biometeorological conditions in the southern Baltic coast based on the universal thermal climate index (UTCI). Theor Appl Climatol 134(1-2):363-379

Kong Q, Zheng J, Fowler HJ, Ge Q, Xi J (2018) Changes in summer thermal conditions in China. Theor Appl Climatol 137:1077-1088. https://doi.org/10.1007/s00704-018-2648-5

Kornhuber K, Osprey S, Coumou D, Petri S, Petoukhov V, Rahmstorf S, Gray L (2019) Extreme weather events in early summer 2018 connected by a recurrent hemispheric wave- 7 pattern. Environ Res Lett 14:054002

Kotas P, Twardosz R, Nieckarz Z (2013) Variability of air mass occurrence in southern Poland (1951-2010). Theor Appl Climatol 114(34):615-623

Kysely J (2010) Recent severe heat waves in Central Europe: how to view them in a long-term prospect? Int J Climatol 30:89-109. https://doi. org/10.1002/joc. 1874

Kysely J, Domonkos P (2006) Recent increase in persistence of atmospheric circulation over Europe: comparison with long-term variations since 1881. Int J Climatol 26:461-483

Leckebusch GC, Weimer A, Pinto JG, Reyers M, Speth P (2008) Extreme wind storms over Europe in present and future climate: a cluster analysis approach. Meteorol Z 17:67-82

Lhotka O, Kyselý J (2015) Characterizing joint effects of spatial extent, temperature magnitude and duration of heat waves and cold spells over Central Europe. Int J Climatol 35:1232-1244

Lin TP, Matzarakis A (2011) Tourism climate information based on human thermal perception in Taiwan and Eastern China. Tour Manag $32: 492-500$

Makkosza A (2013) Bioclimatic conditions of the Lubuskie Voivodeship. Geogr Pol 86:37-46

Mann HB (1945) Nonparametric tests against trend. Econometrica 13(3): 245-259

Marsz AA, Styszyńska A (2000) Variability to the frequency of occurrence of masses of maritime air over northern and Central Poland in the 18th to 20th centuries. Geogr Pol 73(2):127-135

Matzarakis A, Muthers S, Rutz F (2014) Application and comparison of UTCI and PET in temperate climate conditions. Finisterra 49(98): 21-31

Meehl G, Tebaldi C (2004) More intense, more frequent, and longer lasting heat waves in the 21st century. Science 305:994-997

Milewski P (2013) Application of the UTCI to the local bioclimate of Poland's Ziemia Kłodzka region. Geogr Pol 86:47-54

Mohammadi B, Gholizadeh MH, Alijani B (2018) Spatial distribution of thermal stresses in Iran based on PET and UTCI indices. Appl Ecol Environ Res 16(5):5423-5445

Morabito M, Crisci A, Messeri A, Capecchi V, Modesti PA, Gensini GF, Orlandini S (2014) Environmental temperature and thermal indices: what is the most effective predictor of heat-related mortality in different geographical contexts? Sci World J 2014:1-15

Muthers S, Laschewski L, Matzarakis A (2017) The summers 2003 and 2015 in south-west Germany: heat waves and heat-related mortality in the context of climate change. Atmosphere 8(11):224 
Nastos PT, Matzarakis A (2012) The effect of air temperature and human thermal indices on mortality in Athens, Greece. Theor Appl Climatol 108(3-4):591-599

Ndetto EL, Matzarakis A (2015) Urban atmospheric environment and human biometeorological studies in Dar es Salaam, Tanzania. Air Qual Atmos Health 8:175-191

Nemeth A (2011) Changing thermal bioclimate in some Hungarian cities. Acta Climatol Chorol Univ Szegediensis 44-45:93-101

Nowosad M, Rodzik B, Wereski S, Dobek M (2013) The UTCI index in Lesko and Lublin and its circulation determinations. Geogr Pol 86(1):29-36

Okoniewska M, Więcław M (2013) Long term variability of bioclimate conditions in the second half of the 20 century based on Universal Thermal Climate Index (in Polish). J Health Sci 3(15):116-129

Owczarek M (2018) The influence of large-scale factors on the heat load on human beings in Poland in the summer months. Theor Appl Climatol 137:855-869. https://doi.org/10.1007/s00704-018-2633-z

Owczarek M, Filipiak J (2016) Contemporary changes of thermal conditions in Poland, 1951-2015. Bulletin geography. Phys Geogr Ser 10: $31-50$

Plavcová E, Kyselý J (2016) Overly persistent circulation in climate models contributes to overestimated frequency and duration of heat waves and cold spells. Clim Dyn 46(9-10):2805-2820

Półrolniczak M, Szyga-Pluta K, Kolendowicz L (2016) Bioclimate of the chosen cities in the Polish Baltic Coast based on Universal Thermal Climate Index. Acta Geograph Lodziensia 104:147-161 (in Polish)

Porębska M, Zdunek M (2013) Analysis of extreme temperature events in Central Europe related to high pressure blocking situations in 20012011. Meteorol Z 22(5):533-540

Provençal S, Bergeron O, Leduc R, Barrette N (2016) Thermal comfort in Quebec City, Canada: sensitivity analysis of the UTCI and other popular thermal comfort indices in a mid-latitude continental city. Int J Biometeorol 60(4):591-603

Psikuta A, Fiala D, Laschewski G, Jendritzky G, Richards M, Błażejczyk K, Mekjavič I, Rintamäki H, de Dear R, Havenith G (2012) Validation of the Fiala multi-node thermophysiological model for UTCI application. Int J Biometeorol 56(3):443-460

Rozbicka K, Rozbicki T (2017) Variability of UTCI index in South Warsaw depending on atmospheric circulation. Theor Appl Climatol 133:511-520

Shepherd TG (2014) Atmospheric circulation as a source of uncertainty in climate change projections. Nat Geosci 7:703-708

Sheridan SC, Allen MJ (2018) Temporal trends in human vulnerability to excessive heat. Environ Res Lett 13:043001

Shevchenko O, Lee H, Snizhko S, Mayer H (2013) Long-term analysis of heat waves in Ukraine. Int J Climatol 34:1642-1650

Tibaldi S, d'Andrea F, Tosi E, Roeckner E (1997) Climatology of northern hemisphere blocking in the ECHAM model. Clim Dyn 13:649666

Tomczyk AM (2018) Impact of atmospheric circulation on the occurrence of hot nights in Central Europe. Atmosphere 9(12):474
Tomczyk AM, Bednorz E (2016) Heat waves in Central Europe and their circulation conditions. Int J Climatol 36:770-782

Tomczyk AM, Sulikowska A (2018) Heat waves in lowland Germany and their circulation-related conditions. Meteorog Atmos Phys 130(5):499-515

Tomczyk AM, Półrolniczak, Bednorz E (2017) Circulation conditions' effect on the occurrence of heat waves in western and southwestern Europe. Atmosphere 8(2):31

Tomczyk AM, Bednorz E, Półrolniczak M, Kolendowicz L (2019) Strong heat and cold waves in Poland in relation with the largescale atmospheric circulation. Theor Appl Climatol 137(3-4): 1909-1923

Unkašević M, Tošić I (2015) Seasonal analysis of cold and heat waves in Serbia during the period 1949-2012. Theor Appl Climatol 120:29 40

Urban A, Kyselý J (2014) Comparison of UTCI with other thermal indices in the assessment of heat and cold effects on cardiovascular mortality in the Czech Republic. Int J Environ Res Public Health 11:952-967

Urban A, Hanzlíková H, Kyselý J, Plavcová E (2017) Impacts of the 2015 heat waves on mortality in the Czech Republic - comparison with previous heat waves. Int J Environ Res Public Health 14(12):1562. https://doi.org/10.3390/ijerph14121562

Ustrnul Z, Czekierda D, Wypych A (2010) Extreme values of air temperature in Poland according to different atmospheric circulation classifications. Phys Chem Earth 35:429-436

Ward JH (1963) Hierarchical grouping to optimize an objective function. J Am Stat Assoc 58:236-244

Wibig J (2012) Has the frequency or intensity of hot weather events changed in Poland since 1950? Adv Sci Res 8:87-91

Wibig J (2018) Heat waves in Poland in the period 1951-2015: trends, patterns and driving factors. Meteorol Hydrol Water Manag 6(1): $37-45$

Wibig J, Podstawczyńska A, Rzepa M, Piotrowski P (2009) Heat waves in Poland - frequency, trends and relationships with atmospheric circulation. Geogr Pol 82:33-45

WMO No 485 (2010) Manual on the global data-processing and forecasting system, Vol. I - Global Aspects, Geneva

Wypych A, Bochenek B, Różycki M (2018) Atmospheric moisture content over Europe and the northern Atlantic. Atmosphere 9(18). https://doi.org/10.3390/atmos9010018

Yarnal B (1993) Synoptic climatology in environmental analysis. Belhaven Press, London

Zveryaev II (2004) Seasonality in precipitation variability over Europe. J Geophys Res 109D5

Zveryaev II, Wibig J, Allan R P (2008) Contrasting interannual variability of atmospheric moisture over Europe during cold and warm seasons. Tellus A 60:32-41

Publisher's note Springer Nature remains neutral with regard to jurisdictional claims in published maps and institutional affiliations. 